\title{
KOVÁCS TERÉZ: GAZDAPORTRÉK
}

\author{
(Agroinform Kiadó, Budapest, 2008. 128 o.) \\ LUDESCHER GABRIELLA
}

$\mathrm{Az}$ elmúlt hetven év alatt nagy változások mentek végbe a mezögazdaságban és a föld-birtokviszonyban, melyeknek voltak áldozatai és kedvezményezettjei. A Gazdaportrék címú könyvben Kovács Teréz ezen változások hatásait tárgyalja az egyéni gazdák esetében. A kỏnyv témája szorosan kapcsolódik a Szerző eddigi szakirodalmi tevékenységéhez, mint például a Vidékfejlesztési politika címủ mủvéhez, illetve a kétévente általa megrendezésre és szerkesztésre kerülő Falukonferenciához.

A könyv három fejezetet foglal magában, melyek szorosan egymásra épülnek.

Az első fejezet a bevezetést és a módszertani megalapozást tartalmazza. A bevezetésben érdekességként megismerhetjük az egyéni gazdaságok által használt termőföldterületek megyénkénti arányát, mely jelentős különbséget mutat, valamint a termőföldterületek használatát mủvelési ágak szerint. Megtudhatjuk azt is, hogy a tanulmány kiknek a segítségével és szellemi támogatásával született meg.

Az első fejezet öt alfejezetre tagolódik. Az első alfejezetben a Szerzó bemutatja az egyéni gazdaságok fejlesztése érdekében megszületett kormányzati döntéseket, melyek lehetővé tették a gazdák földhöz jutását. A Szerző ebben az alfejezetben ismerteti továbbá az eddig biztosított beruházási támogatásokat, valamint azokat a rendelkezéseket, amelyek megteremtették a családi gazdaságok létrehozásának és fejlesztésének jogi hátterét. A második alfejezet a kutatás célját és hipotézisét fogalmazza meg. A következő alfejezetben a központi fogalmak meghatározása történik. Központi fogalmak a föfoglalkozású egyéni gazda, habitus, siker és élettörténet. Ezek a fogalmak megjelennek az élettörténetek bemutatásakor és elemzésekor. A negyedik alfejezetben a kutatás módszertanát ismerhetjük meg. A Szerzỏ elemzésében mintegy harmincnégy olyan életút leírását használta fel, amelyek 2005-ben készültek Hajdú-Bihar és Baranya megyében. Az elemzéshez Kovács Teréz felhasználta még az erre a célra készült harminc föfoglalkozású egyéni gazdával készült élettörténeti interjú adatait is. Az interjúalanyok negyven év feletti férfiak, akik egyéni gazdák és agrárvállalkozások menedzserei. Húsz interjút a Szerző készített, tízet pedig Bögre Zsuzsanna.

Az utolsó alfejezetben a gazdák tipizálása és definiálása történik habitus, vállalkozásuk nagysága és a gazdák fejlesztési szándéka szerint. A vizsgálat során a Szerzó a gazdák körében hat habitust különböztet meg, melyek az alábbiak: paraszti, utóparaszti, parasztpolgári, produkcionista menedzseri, technokrata menedzseri és vállalkozói. A Szerző a vállalkozások nagysága szerint megkülönböztet kisvállalkozókat, középvállalkozókat, közép-nagyvállalkozókat és nagyvállalkozókat. A gaz- 
dákat a fejlesztési szándékaik szerint három típusba sorolja Kovács Teréz: elbizonytalanodó, szünetelteti a fejlesztést, biztos fejlesztö. Végül ez az alfejezet egy kiváló kereszttáblázattal zárul, melyben a habitusvariációk a vállalkozók nagyságával és a fejlesztési szándékkal vannak párosítva. Például a paraszti-utóparaszti habitussal rendelkező gazda vállalkozói nagysága kicsi, fejlesztési szándéka elbizonytalanodó, míg a vállalkozói-parasztpolgári habitussal rendelkező gazda vállalkozása nagy és biztos fejlesztő.

A második fejezet - élettörténetek bemutatása és elemzése - azoknak is élvezetet nyújt, akik az elsỏ fejezetet átugornák.

A Szerző a harminc interjúból a tíz legtipikusabb élettörténetet választotta ki. Ezek az élettörténetek hozzájárulnak a mezögazdasági vállalkozásokra vonatkozó társadalmi ismereteink bővítéséhez.

Ezt a fejezetet három alfejezetre osztotta a Szerző a tíz gazda fejlesztési szándéka szerint. Az elbizonytalanodók tábora három gazdából áll, ketten vannak, akik szüneteltetik a fejlesztést, míg a biztos fejlesztők csoportját öt személy alkotja. A tanulmány egyenként mutatja be a tíz interjúalanyt. Az elemzési módszer mind a tíz interjúnál azonos. Minden élettörténetet négy szakaszra tagol a Szerző: megismerjük a gazdák gyermekkorát, tevékenységét a szocializmus alatt és a rendszerváltás után, végül a jövőképüket. Az interjúk minden esetben kiegészülnek a Szerző élettörténettel kapcsolatos megjegyzésével. Ezen életszakaszok kirajzolják a gazdák portréit.

A Szerzőnek sikerült olyan érdekes élettörténeteket kiválasztani az elkészült interjúkból, melyek nemcsak hủen reprezentálják a mezőgazdaságban végbement változásokat, hanem szociológiailag is megragadhatóvá teszik azt, hogy egy gazda habitusa mire képes. A Szerző rámutat arra, hogy a gazdák habitusa, világhoz való hozzáállása és munkaszeretete nagyobb hatással van az egyéni gazdaságra, mint a tőkével való ellátottság.

A bemutatott élettörténetek alkalmasak másodelemzésre is, mivel magukban rejtenek olyan többlet információt, amely más szemszögből is vizsgálatra érdemes.

A harmadik fejezet a Szerzó következtetéseit tartalmazza, melyeket az elemzés alapjául szolgáló mélyinterjúkból von le. Az Autor álláspontja szerint ezek az interjúk nem elegendőek a szigorú tudományos konklúziók levonására, de tendenciák felvázolására alkalmasak. Kiragadnék ezen megállapításokból néhányat, melyek különös jelentőséggel bírnak. Így például az a következtetés, mely szerint a gazdák vállalkozásának fejlődése szempontjából nagyon fontos, hogy honnan vették a mintákat a vállalkozásuk kialakításához. A Szerzỏ kutatása szerint eredményes gazdaságot kialakítani többnyire azok tudtak, akik a hetvenes-nyolcvanas években nagyban „háztájiztak”.

A következtetéseket tartalmazó fejezet négy alfejezetre oszlik. Az első alfejezetben a posztszocializmus és az új kapitalizmus időszakának lehetőségeit, valamint nehézségeit ismerteti a könyv. A második alfejezet „A gazdák a siker függvényében” címet viseli. A Szerző külön-külön vizsgálja a fejlesztési szándék szerint besorolt három csoportot (elbizonytalanodók, fejlesztést szüneteltetők, biztos fejlesztők). 
Megállapítható, hogy az elbizonytalanodók inkább áldozatai, mint nyertesei az átalakulásnak. Azok a gazdák, akik szüneteltetik a fejlesztést, azok sikeressége és pozitív önértékelése is kétséges. Azok a gazdálkodók, akik biztosan fejleszteni fognak, sikeresnek érzik magukat.

A harmadik alfejezetben a habituskombinációkat és azok vélt okait ismerhetjük meg. A különböző habitusok kombinációi a Szerző szerint a megváltozott makroszintủ társadalmi változásokra adott mikroszintű válaszok. Habituskombináció Kovács Teréz álláspontja szerint azért alakulhatott ki, mert azok a gazdák, akik az elsődleges habitus-típussal nem boldogultak, változtattak a gazdasági viselkedésükön.

A negyedik alfejezet címe kérdéssel indít. A Szerző felveti, hogy a fejlödő gazdaságból profitál-e a falu? A tanulmányban választ is kapunk a feltett kérdésre a Szerző segítségével. Kijelenthetô, hogy ha fejlődik egy egyéni gazdaság, akkor e fejlődésből a helyi társadalom is profitál, hiszen nem csak munkahelyet teremt a maga vagy más/mások számára, hanem jó mintául is szolgálhat.

A könyv ismertetése után fontosnak tartjuk bemutatni e szakkönyv erösségét is. A Szerző nagy precizitással dolgozott, mely mind a mélyinterjúk készítésének alaposságánál, mind azok elemzésénél megjelenik. A világos, érthető fogalmazás, valamint a tanulmányban használt szakkifejezések részletes magyarázata lehetővé teszi, hogy az alapvetően szakkönyvnek szánt tanulmány azok számára is élvezetes olvasmányt nyújtson, akik a mezőgazdaságban végbement folyamatokkal, valamint ezek szociológiai vonatkozásaival közelebbi kapcsolatban nem állnak.

A könyv további pozitivuma az is, hogy a Szerző az interjúkhoz kapcsolódó mezőgazdasági tevékenységeket megmagyarázza, például hogyan nyársaltak és arattak kézzel, mi a pétisózás, avagy mit értünk teheneknél kötetlen tartás alatt stb. A fenti magyarázatok sokat segíthetnek azoknak, akiknek nincsen elemi tapasztalatuk a mezögazdaságról, az őket körülvevő természeti környezetről. A könyvben szereplö magyarázatok lábjegyzetekként jelenek meg, így nem engedik az Olvasót elsiklani olyan dolgok fölött, melyekről vélhetőleg nem áll rendelkezésére elegendő információ.

A tanulmány erősségeként azt is szükséges megemlítenünk, hogy a Szerző a Gazdaportrék megjelentetésével nem csak (!) kizárólag a tudomány hasznára tett, hanem emellett próbálja visszaadni ezen gazdák tekintélyét a mai generáció szemébe.

A Szerző könyve alapján részletes betekintés nyerünk az egyéni gazdák habitusába. A mủ az utolsó földbirtokviszony-változás hatásait mutatja be az azonos társadalmi állású családoknál. Ezekről a jelenségekről keveset tudunk, így a könyv elérte a fö célját: nagyban hozzájárult tudásunk bővítéséhez ezen a területen.

Ugyan már sokan foglalkoztak az e könyv által érintett területekkel, de még eddig senkinek sem sikerült ilyen részletes portrét ,rajzolni” az egyéni gazdák habitusáról, mindezt könnyen értelmezhető módon és újszerüen. 
Tér és Társadalom 23. évf. 2009/1. 219-238. p.

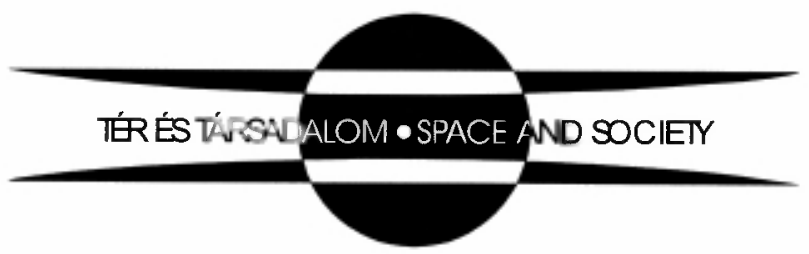

